\title{
In the Shadow of Jakarta: City, Migrants and Exploitation in Secangkir Kopi Pahit
}

\author{
Gaston Soehadi1 ${ }^{\text {a) }}$ \\ ${ }^{1}$ Faculty of Letters Petra Christian University \\ a) Email:gastonsoehadi@yahoo.com \\ . DOl:https://doi.org/10.18196/jkm 101009
}

Article Info

Article history: Received 24Sept 2018 Revised 24Sept 2018 Accepted 27Okt 2018

\section{ABSTRACT}

This article examines Secangkir Kopi Pahit (Bitter Coffee, 1985), Teguh Karya's tenth feature film, in which the film uses a non-linier investigative narrative structure to tell a complex story of an urban migrant coming to live in Jakarta. Unlike his previous films, in Secangkir Kopi, Teguh develops a new and unique filmic storytelling approach (using complex flashback structure in addition to filming location; central character a photographer and reporter obsessed with the city and exposing situations), which arguably produces a reality effect in depicting the growing third world megacity of Jakarta in the early 1980s. Secangkir Kopi Pahit combines and arranges various plots to portray the experience of people living in a late $20^{\text {th }}$ century, third world megacity. The use of a complex narrative form from the beginning puts pressure on the viewer's capacity to comprehend events in the film.

Key words: third cinema, narrative, realism, megacity, village, migrants

\section{ABSTRAK}

Artikel ini mendiskusikan teknik bercerita dalam film Secangkir Kopi Pahit (Bitter Coffee, 1985), yang merupakan film ke sepuluh karya Teguh Karya. Berbeda dari film-film Teguh sebelumnya yang beralur cerita kronologis, jalinan cerita Secangkir Kopi Pahit bertumpu pada struktur narasi yang tidak runtut, lokasi syuting yang berpindah-pindah dan teknik kilas balik investigasi yang berlapis untuk menggambarkan peristiwa yang dialami para pendatang di kota Jakarta. Tokoh sentral yang berprofesi sebagai wartawan dan yang terobsesi untuk merekam kehidupan para pendatang lewat pena dan kamera jurnalistiknya menambah efek realistis dalam film ini. Secangkir Kopi Pahit adalah gambaran kota metropolitan Jakarta pada tahun 1980an lewat jalinan cerita, gambar dan peristiwa melalui penuturan tokoh-tokohnya.

Kata kunci: Sinema ketiga, narasi, realisme, metropolitan, desa, migrant 


\section{INTRODUCTION}

Secangkir Kopi Pahit is one of Teguh Karya's most significant films. Unlike Teguh's previous films Usia 18 (1980) and Di Balik Kelambu (1982), which deal with social problems confronted by families, Secangkir Kopi Pahit takes on social issues of a national and global significance, including the migration of people from rural regions to the national capital, the increasingly large megacity, Jakarta. In this film, the narrative focuses on the experience of a young Batak Indonesian, a migrant from the Lake Toba area in North Sumatra, Togar, who, like many other people from regional areas, is moving in search of a better life in Jakarta. If Usia 18 is an impressionistic portrait of a young man as a family breadwinner, and Di Balik Kelambu a naturalistic picture of the struggle of a married couple living in kampung, Secangkir Kopi Pahit attempts to describe a man's experience as a young migrant in which his life becomes a microcosm for the pressures placed on many people by the conditions of existence in this difficult city. One important reason why Jakarta is often seen by regional people as a kind of magnet towards which they must inevitably move is that all economic activities are concentrated there, rather than in their own regions; and this was particularly true of New Order Indonesia.

While Secangkir Kopi Pahit is particularly concerned with the journey of its main character, the story also gives a glimpse of the lives of other internal migrants' living in the same city. Indeed, most of the (main) characters in this film (Togar, Buyung, Mangara, Lola, Sukarsih and Parjo) are people from other regions of Indonesia who are trying to make a living in Jakarta. Given its theme, length of shooting (two years) and shooting locations that include Jakarta, West Java (Cirebon) and North Sumatra, Secangkir Kopi Pahit may be considered as Teguh's most ambitious effort to make a film that illustrates the social problems of the Indonesian nation as a whole ${ }^{1}$. Apart from its experimental narrative, the film is important sociologically speaking because it is the only film where Teguh openly and directly talks about Jakarta. What the film mainly tries to do is to experiment with the film form in order to portray as starkly as possible people who are culturally and economically displaced in the city, and subject to the pressures of an economy in which they must fight to find a place. Therefore, my analysis of Secangkir Kopi Pahit will explore the way the film conceives the experience of its characters as they live in the third world megacity of Jakarta.

\section{Third Cinema}

The concept of "third cinema", developed by Teshome Gabriel (1989), is relevant to an analysis of Secangkir Kopi Pahit. Although in earlier essays Gabriel views third cinema as mainly representing the political interests of the Third World as opposed to the First and Second Worlds with their highly commercial filmmaking or "bourgeois" art films, in his later writings, Gabriel, in his latest writings, revised his views, doing away with binary oppositions and emphasizing that third cinema is dynamic and always changes over time.

"I began, in short, to think of third cinema less in terms of typologies and structural oppositions than in terms of various cultural metaphors that suggested more complex, non-binary relations. This shift was, no doubt, a reflection of changes in

\footnotetext{
${ }^{1}$ The original title is M erobek Angan-Angan. But, in the course of the production ( 2 years), it changed to Secangkir Kopi Pahit (M arselli, 1985)
} 
third cinema itself, but also of more general changes in cultures and cultural theories." (Gabriel, n.d)

Gabriel departs from this early view of third cinema as primarily the radical voice of Third World people to his mature understanding that third cinema is less unified in its shape than he had argued in his earlier writings. In its representation of the emergence of diaspora, third

Page | 102 cinema represents not one but many voices, each of which has its own cultural dynamic. For Gabriel, the term "third cinema" becomes "third cinemas", in order to signify various identities in the movement. A case could be made that with its extensive use of flashbacks Secangkir Kopi Pahit does emphasize identity and memory. This further represents the way third cinema should be perceived as "a space for a variety of approaches, styles and projects" (Gabriel, n.d). Taking further the diversities of storytelling or narratives, third cinema painstakingly attempts to describe people in everyday life. Bordwell (1985) argues, "Most studies of realism or character in fiction exemplify an interest in narrative as representation." This study of Secangkir Kopi Pahit is an exploration on the film narrative as a representation of people's urban experience in a third world megacity of Jakarta.

\section{A Short Biography of Teguh Karya}

Teguh Karya or Steve Liem Tjoan Hok was born in Pandeglang Banten on 22 September 1937 where he spent part of his childhood. When Teguh was about nine years old, he and his family fled from the village to avoid a riot that destroyed the village and his home. Teguh and his family resided in Jakarta where he continued his schooling. In 1955, following his graduation from junior high school, he went to study at Film and Drama Academy (ASDRAFI) Jogjakarta, but was dropped out. He returned to Jakarta and spent two years without jobs. In 1957, he applied as a non-registered student at Indonesian National Theatre Academy (ATNI) in the morning while trying to gain a high school certificate in the evening. After gaining the certificate, Teguh became a full time student at ATNI where he was taught and influenced by his teachers, Usmar Ismail, Asrul Sani and Djajakusuma. He graduated in 1961 and worked as a stage manager at Hotel Indonesia. He received a scholarship to study art directing at East-West Centre Hawaii in 1963, which he did not finish due to illness. Teguh returned to ATNI and taught Iconography for several years (1964 - 1968). He was also still working at Hotel Indonesia. He formed a collective called Teater Populer Hotel Indonesia in 1968. Among the members were his former ATNI students such as Slamet Rahardjo, Riantiarno, Boyke Roring; a fellow stage actor, Henky Sulaiman; and a lecturer at Universitas Indonesia, Tuti Indra Malaon. In 1971, Teater Populer was no longer supported by Hotel Indonesia. Teguh, with the help of the members of the collective began to manage the group's performances. However, due to the financial difficulties faced by the collective, Teguh decided that they had to enter the film industry, which was flourishing in the early 1970s. Teguh and Teater Populer made 13 films that would establish his reputation as one of the most important and original film auteur in Indonesia: Wajah Seorang Laki-Laki (1971), Cinta Pertama (1973), Ranjang Pengantin (1974), Kawin Lari (1975), Perkawinan Dalam Semusim (1976), Badai Pasti Berlalu (1977), November 1828 (1978), Usia 18 (1980), Di Balik Kelambu (1982), Secangkir Kopi Pahit (1985), Doea Tanda Mata (1985), Ibunda (1986) and Pacar Ketinggalan Kereta (1989). 


\section{The Plot}

Secangkir Kopi Pahit is concerned with the journey of Togar (Alex Komang in his first performance as a film actor) from Lake Toba in North Sumatra to Jakarta. The film opens on Lake Toba with a dramatic scene in which a drowned woman's body is brought ashore from the lake, while her distraught husband, Togar, cries out, exhorting local citizens never to be tempted to go to Jakarta. The woman's name is Lola. An investigation by the local court is to be held as to the circumstances of Lola's death, and because Togar was driving the boat from which she fell and drowned, his role in her death is the focus of the investigation. The film then moves into flashback mode, as the court judge begins to examine the case, with Togar sitting in the chair as the main suspect. His former university lecturer at school of law, Simorangkir (Maruli Sitompul) acts as his defense lawyer. Most of the subsequent film is told in flashbacks, with the film returning to the court a number of times, most importantly at the end where the verdict is announced. In the first flashback, we learn that Togar was sent by his parents to study in Jogjakarta, but he found that he did not like what he studied. Although his parents wanted him to study economics, he actually wanted to become a journalist. Dropping out of university, Togar goes to Jakarta to fulfill his dream of becoming a journalist. His friend Buyung (Ray Sahetapy) who is already a journalist working for a newspaper, helps Togar find work at his newspaper. As a junior news reporter struggling with the lack of journalistic experience, Togas is called to investigate a case of a girl named Sukarsih (Dewi Yull), who has become a victim of slave traders running a prostitution ring. She had been promised a job as a housemaid by, what she believed, an employment agent in Jakarta, but is then raped by Parjo, one of the leaders of the ring.

While Togar struggles to investigate the case of Sukarsih in which he is also accused of kidnapping her, he is told that Lola with whom he has an uneasy relationship is pregnant with his child. Although this news upsets him in the beginning, Togar accepts his responsibility and comes to realize that he must marry Lola. Buyung, who gets back his job after being suspended by the paper, continues Togar's work and finds Sukarsih working at a food stall in the crowded lower class market area. Buyung brings Sukarsih to the police station where she confesses that she escaped from the traders because she was raped by one of them. Togar is cleared of any accusations. The sudden news from his village of his father's death causes him to return back home to Toba. Togar's return to his village turns into a tragedy after a boat accident where Lola is drowned on a lake. The film then flashes forward to the judge's verdict on Togar. It is announced that he is free from all the charges.

\section{DISCUSSION}

There are several aspects that make Secangkir Kopi Pahit one of Teguh's most significant films. Firstly, in relation to form, the film uses a non-linear investigative narrative structure to tell the complex story of an urban migrant coming to live in Jakarta. Secondly, thematically speaking Secangkir Kopi Pahit represents Teguh's most powerful portrait of exploitation and distress experienced by groups living in Third World conditions in Indonesia. This film is more capable of dealing with the complexity of these issues than the more formulaic melodrama, Perkawinan Dalam Semusim (1976), where exploitation is 
seen largely in personal terms rather than as a systemic problem. Thirdly, although Secangkir Kopi Pahit describes the exploitation of human beings in the megacity, the film should not be mainly regarded as a melodrama, for the use of the flashback structure allows the film to explore experience, motivation and cause, rather than to highlight victimization, while at the same time providing ironic contrasts and parallels in its vision of the city, as Page | 104 individuals discuss Jakarta with Togar or report to the court (via voice overs) what they have witnessed. And through its contrast between the city and the village, Secangkir Kopi Pahit raises the important issue of the economic viability of regional areas.

Firstly, I want to address the different kinds of realism in the film. To a certain extent the opening credits of Secangkir Kopi Pahit are reminiscent of Usia 18, because both films use black and white still photographs as background to the credits. However, unlike Secangkir Kopi Pahit, the opening credits of Usia 18 show a series of family photos, as if the credits were displaying images from a family photo album as a way of introducing its characters. The generic style of the stills used in the credits of Secangkir Kopi Pahit is not of the family photograph, but photojournalism. The film uses journalistic still pictures of citizens of various backgrounds located outside of a family context, for example in their workplace or the street, as illustrations of the lives of ordinary but anonymous people, unposed photographs mainly of poorer people. The photos in the opening credits show (in the following order): a group of poorly dressed migrant men and woman, looking anxious, filmed obliquely, party in silhouette; a young boy selling newspapers at a traffic intersection, seen from a bus; a group of primary school children in school clothes, emerging from their village school; and a young man clutching a still camera, standing by a van. This last image, which is of Togar, is held for much of the credits. As the film continues to display these pictures as background to the credits, the sound of energetic typewriting on an old typewriter starts up on the soundtrack.

As we discover later, most of these photos were taken by the central character, Togar, as part of his work. He is shown to be personally obsessed with the city. But the series of still shots are the means by which the film discovers a more complex kind of realism, not simply the naturalistic observation of family life in the city, as we have in $D i$ Balik Kelambu and Usia 18, but reportage of the visual face of both city and village. Similar images of anonymous people occur throughout the film, sometimes not simply as individual still photos but as montages of moving images. In its concluding moments, the film shows a series of shots that depict young boys selling newspapers on the street (presumably to pay for their education); a young boy who is washing a car; crowds of school children coming out of their school at the end of the day; a group of factory workers (this time posing for Togar who is now back at work); and a smiling tricycle driver. In a way, these last documentary-style images sum up a potential future for Indonesia.

It is within a context of this more urgent and graphic realism that we find the complex jigsaw-puzzle-like investigative flashback structure used by the film. The film begins with the death of Lola but then moves into the past to investigate the circumstances of her death. Two other films by Teguh, Wajah Seorang Laki-Laki (1971) and Ranjang Pengantin (1974), also begin with a tragic event and then move into the past to show the personal history of the central characters that culminated in the tragic circumstances with which the films open. In these two films, the reason for beginning in this way is simply to engage the audience emotionally in the stories. In Secangkir Kopi Pahit, however, this 
stratagem of beginning at the end is used in order to initiate an investigation, which, while being conducted by a court, is in fact an investigation into the set of social circumstances surrounding the death and the moral behavior of the central character within these circumstances, all of which reflect upon the difficulties - for a migrant—of living in Jakarta. Moreover, whereas the two earlier films are primarily linear in structure, except for the opening flash-forward, the subsequent development of Secangkir Kopi Pahit after its opening flashback, is not linear but a further series of flashbacks (and flashbacks within flashbacks), in which the film jumps from one situation to another, and then forward again to the court before returning to another set of events, which we sometimes discover are retrospectively told by another observer. Additionally, the movement between different parts of the past is not accompanied by a facilitating transitional device such as a slow dissolve, but by direct cuts, which further emphasize the abrasive nature of the story the film is unfolding.

The original title for the film was Merobek Angan-Angan (Torn Imaginings) and, in the scene immediately following the death of Lola, the central character, Togar, is shown flailing a coat around himself and with despairing anguish exhorting people in a nearby procession on a street in the lakeside town not to go to Jakarta, for this will be the source of tragedy. This procession is celebrating the departure of a young man who is leaving the region to begin his education in Jakarta. The use of handheld camera and the sardonic music in the background sets up an irony even in the beginning of the story. We see Togar with his ulos (a traditional Batak cape) trying to disperse the parade, and we hear him cry out "What's all this for?" and "There are still many things that you can do here (Untuk apa ini semua. Masih banyak yang bisa diperbuat di sini)!" Before he is able to stop the procession, Togar is punched by the leader of the parade, in order to stop him interrupting the procession. Then the film shifts to the tribunal where it will conduct the investigation of Lola's death and Togar's possible involvement in it. It is from here that the film transitions to the past, and it does so in a way where the viewer is positioned as a judge of Togar's actions, not simply examining his inattention as the driver of the boat at the time of Lola's fall into the water but all of his actions from the time he left home to go to Jakarta. These include scenes that show not only his growing attachment to Lola, who is older than him, but scenes of domestic violence towards Lola, as the lonely and drunken Togar is unable to fully understand his need for Lola and expresses his ambivalence towards her. These scenes are also witnessed by the children from her first marriage, so that children become judges of adult behavior.

One of the events that the film investigates and in which the use of flashbacks within flashbacks is most interesting is Togar's own investigation, as a junior reporter, of the case of Sukarsih, a village girl from East Java who is being forced into prostitution. This story begins, about twenty-five minutes into the film as Togar goes to the Central Javanese northern coastal town of Cirebon to try to interview Sukarsih. The professionally immature Togar focuses his journalistic attention on Sukarsih, who is sitting with female friends (also being forced to work in Jakarta) outside a small hotel, and Sukarsih reacts towards Togar not as if he were a helper but rather an intrusive stranger. As she flees to a bathroom, Togar follows her and grabs her, trying to use force to entice her to talk about her experiences, and as she fends him off the film cuts back and forth between this scene and the attempted rape of Sukarsih by Parjo, which had occurred earlier in Surabaya but which was witnessed by 
Buyung. This parallel montage between two incidents graphically suggests that Togar's presence reanimates her memories and original trauma of being raped.

The film subsequently flashes forward to an interview, where Togar's employer, the newspaper editor, is giving his testimony for the court. The editor expresses his bewilderment at Togar's obsession with reality in his work as instanced by the numerous

Page 106 photos he takes. He goes on to narrate the subsequent history, explaining that, as a result of covering the Sukarsih case, Togar came to the attention of the police, having been reported by Parjo as having kidnapped Sukarsih, though Sukarsih has in fact simply fled and disappeared in order to escape her oppressors. The film uses flashback within flashback to reveal that Togar and Buyung worked in cooperation to solve the case of Sukarsih and get help for her, with Sukarsih's eventual return proving that Sukarsih herself had fled the employment agency/prostitution ring because she had been raped by one of its key operatives.

The film also uses the convention of interviews (conducted for the court) as part of the investigation of Togar. Togar's mother, his colleague and friend Buyung, the newspaper editor and Rudi (Lola's eldest child) all speak to the camera (and hence to the viewer) when they provide information or testimonies about Togar and Lola. However, these witnesses do not appear to be present in the court. For example, the newspaper editor speaks from his newsroom, across his desk, and Rudi speaks while sitting in a corner of a house. In a flashforward, Togar's mother speaks from her house. In presenting the court itself, for much of the time, the film uses only voice-overs of statements by officials of the court, heard as background to images. For example, during the court examination, the film does not visually focus much on the court judge or court officials. They are mainly present as off-screen voices, or as a voice over, particularly at the end of the film when Togar is found not guilty of the murder charges. Both the direct address by the interviewees to the camera and the relative absence of the visual presence of court officials further helps position the viewer as primary judge of Togar's behavior.

As the narrative progresses, the examination of the crime turns into an examination of the moral struggles of its main character, including his humanity. In addition to showing Togar's confusion, the film also takes an interest in how Togar attempts to address the problems of his life in Jakarta and to become more compassionate and generous in his outlook. Although Togar's life is nomadic, he is described in the interviews as showing tolerance towards his friends. For example, when Buyung needs money to help his parentsin-law come to Jakarta Togar lends money to him so they can stay in a cheap motel. Although Mangara refuses to let Togar stay in his apartment, Togar does not dismiss his friendship with Mangara but does reject Mangara's offer to bribe Parjo to withdraw the accusation of kidnapping Sukarsih. However, it is the changes in his relationship with Lola that receives the most emphasis in the narrative. Initially, the film presents a critical portrait of Togar, who lacks self-confidence and can also be violent. Togar is psychologically affected by several facts in his life: his failure at university, his inability to realize his parents' dreams, and the subsequent uncertainty of his life in Jakarta as a cement factory worker, writer and journalist.

By showing these two sides of Togar, the film attempts to reveal a complicated life of a young migrant in Jakarta. Visually, the film demonstrates his growing maturity through the sequence of shots when Togar is informed that Lola is pregnant with his baby. The first 
shot is a close-up of Togar's face upon receiving the news of Lola's pregnancy and the demand that he must marry her. This shot is followed by the shot in his village where his mother sits on the floor, making ulos. She speaks about her hopes for Togar. The next shot shows Togar on his bed, having become ill as he comes to realize that he must take responsibility for Lola. The last shot describes in a flashback (within a flashback) of him in the procession that occurred to celebrate his departure to Java few years ago. This sequence of shots, emphasizing Togar's feeling, is excellent in signifying another "bitter" transition in Togar's life, as he moves from being single to becoming a husband. However, Buyung states that Togar becomes a more mature person through dealing with this situation. We also see the ecstasy on his face as he sees the child that Lola has borne him.

Given the complexity of Secangkir Kopi Pahit, and the vision of the modern Third World city it offers, the film is clearly a milestone in the work of Teguh Karya. But Secangkir Kopi Pahit should be not be perceived primarily as either a melodrama or a naturalistic film. Unlike Perkawinan Dalam Semusim, which explores the exploitation of women and the poor people who live around the volcano by the males of one rich local family, Secangkir Kopi Pahit explores the negative impacts of living in the city in the lives of migrants. What Secangkir Kopi Pahit does here is to expose the exploitation mainly committed by the system towards the people who live within it. In other words, Secangkir Kopi Pahit tries to define the kind of exploitation committed in the Third World city and the experience of being exploited by the pressures that exists in the city. It is not only Togar and Lola who suffer in the city; the film presents the even more extreme case of Sukarsih, who is tricked into becoming a prostitute and victimized by one of the traders, Parjo. Sukarsih should also be perceived as a victim of the system because Parjo is part of the system that exists in the city. In this way, Secangkir Kopi Pahit attempts to demonstrate the pervasive impersonal kinds of exploitation toward human beings that one finds in the city environment. In the period shown in this film, the centralization of the government, business, politics and economy in Jakarta forced people from various regions in Indonesia to come to Jakarta to search for a better life, including education. Through its observations of the experience of being victimized by the system or the city, Secangkir Kopi Pahit shows that these characters are not actually aware of the fact that they are being victimized. For example, it is only when he loses Lola that Togar expresses his hostility to the city.

There are a number of reasons why Secangkir Kopi Pahit should not be considered a primarily melodramatic film. For one thing, it uses an unusually complicated narrative structure that does not allow for the usual satisfactions of melodrama. While the underlying story (the fabula) told in Secangkir Kopi Pahit is simply about Togar's journey in Jakarta, the plot (the organization of the telling of the story, or syuzhet) is not linear. Bordwell (1986) points to the fact that the syuzhet plays a significant role in the viewer's ability to construct the fabula:

"Thus, the syuzhet aims not to let us construct the fabula in some logically pristine state but rather to guide us to construct the fabula in a specific way, by arousing in us particular expectations at this or that point, eliciting our curiosity or suspense, and pulling surprises along the way." (Bordwell, 1986: p.52)

In Secangkir Kopi Pahit the narrative organization breaks down the story into a series of flashbacks, flash-forwards and sub-stories that gives the viewer more than just the description of the main character. The use of this complex narrative form from the beginning 
of the film puts pressure on the viewer's capacity to comprehend events. With a complicated jigsaw-like flashback narrative structure, numerous unmarked transitions between scenes and different chronological times and an average shot length of five seconds, the film demands that the viewer work hard to relate and comprehend the images and events presented by the film.

Page | $108 \quad$ Moreover, Secangkir Kopi Pahit should not be mainly perceived as melodrama because, along with the criminal investigation, the film also examines the moral struggle of Togar in his relationship with other characters, and this is not seen in terms of the simple oppositions between good and evil that are characteristic of melodrama, but in terms of more complex judgments about moral struggles and human failings. At its end, Secangkir Kopi Pahit does not attempt to reach an easy conclusion about the Togar's journey and his moral struggle.

Finally, Secangkir Kopi Pahit differs from Di Balik Kelambu because it is not usually seen as a naturalistic work. Di Balik Kelambu portrays the flow of life or events over a continuous period of time, with as little reorganization of the temporal syuzhet as possible, as is characteristic of naturalistic drama. The narrative of Secangkir Kopi Pahit, on the other hand, does not work linearly over a single slice of time, but is broken up into various dramatic units in different times so as to define the meaning of the experience of the characters, rather than simply to tell a story.

Secangkir Kopi Pahit also demonstrates the contrast between rich and poor as well as between the city and village. In several scenes we see the lives of the lower class people in the city as well as in the country. For example, the film contains an interview with a rubbish picker, another Batak migrant, who salvages cigarette butts and turns them into whole cigarettes. This man lives along the Tanah Abang railway line in Jakarta. Quite unlike Usia 18, where mutual support and mutual solidarity are presented as part of the everyday life of Jakarta families and young people, the concept of mutual solidarity does not come easily in Secangkir Kopi Pahit. There are several examples where even among migrants mutual solidarity is not a common experience. Togar and Buyung help each other, for example when Togar is looking for a job in Jakarta. However, we also see that when Togar asks his friend Mangara if he could stay with him, Mangara refuses him by saying, "In Jakarta, we can't mutually help each other (hidup di Jakarta, kita tidak bisa tolongtolongan)". This is a significant statement because it demonstrates an ideal view of the Indonesian people, that they are people involved in gotong royong (mutual support), but does not apply to all of New Order Jakarta.

In contrast to Jakarta, the depiction of Togar's lakeside village in North Sumatra suggests mainly two things. Firstly, the film presents the villagers who live as a group or community, unlike the characters in Jakarta who largely live as individuals. Secondly, the film presents us with traditional ceremonies in the Batak village, ceremonies that signify people's group identity. Although in one early scene the film describes a group of cement factory workers who often get together in Lola's cafe in Jakarta, similar images of group solidarity among urban workers do not emerge anymore in the rest of the story. After Togar marries Lola, her food stall gradually become quiet. The workers move the place where they meet to the nearby nightclub and brothel where violence frequently breaks out among them. In the beginning of the film, community support is shown when the villagers get together to help carry Lola's dead body. When the police officers bring Togar from the village to the 
police station after the discovery of Lola's dead body, most of the villagers are seen walking as a group following Togar and the police officers, as if the villagers have lost one of their members.

The idea of community support also appears in several other scenes. For example, the solidarity and group identity of villagers, and the continuity of their rituals, is evident in the repeated scenes of the parade, with villagers and musicians celebrating the departure of a young teenage man from the village. This procession is presented as a contemporary phenomenon, occurring more or less at the time the film was made, in the early 1980s. Togar's departure parade, seen in flashback in the middle of the film, presumably occurred in the early 1970s. However the most significant moment with regards to the life in the village is the acceptance by the villagers as a group (especially Togar's mother) of Lola and her children as members of their community. The acceptance of Lola and her children is marked through a traditional ceremony where she and the children are given a marga Batak (clan name). This ethnic ceremony is accompanied by traditional music, specifically musical instruments used by Batak villagers, gondang (drums) and sarune bolon (flute).

As a film that deals with social injustice, Secangkir Kopi Pahit describes the exploitation of young people as they attempt to search for a better life in Jakarta. In relation to who exploits whom, it is interesting to briefly compare Perkawinan Dalam Semusim and Secangkir Kopi Pahit. The story of Perkawinan Dalam Semusim depicts a situation where the majority of poor villagers living in the village near the mountain are exploited or victimized by a small group of rich people or a family living in the city. These rich people take advantage of poor people through the factory that they build near the village. Here, Perkawinan Dalam Semusim clearly shows that there are exploitations toward a group of human beings by other human beings based on the difference of social class background.

Unlike Perkawinan Dalam Semusim, Secangkir Kopi Pahit describes the fact that these migrants, most of whom are of a lower economic background, such as Togar, Buyung and Mangara, struggle against the exploitation created by the environment or the system under which they live, and are changed by it. Togar, for example, is perceived by his mother as a different person when he finally returns to the village. The film reveals that after his departure to Jakarta and Jogjakarta, Togar never sent news to his parents regarding his life in Java. It suggests that he felt so ashamed at what he regarded as his failure in Jakarta (given their aspirations for him) that he was unable even to communicate with his parents. On his return to the Lake Toba area, his mother tells Togar she cannot regard him as her son anymore because Togar did not sent a single letter to his parents or visit his village until he heard of his father's death. She also considers him as not a Batak person anymore because he was too ashamed of telling the truth about his life in Java. However, following Lola's death and the investigation of Togar, the mother states clearly that it is the environment (the system) in Jakarta that should be blamed.

\section{CONCLUSION}

Secangkir Kopi Pahit exemplifies a further journey of third cinema (or rather third cinemas, as suggested by Gabriel) in that it attempts to portray the experience of people living in a late 20th century Third World megacity. Instead of attacking the First World, the film provides a portrait that helps the viewer understand the difficult experience of urban 
migrants in Jakarta. The use of experimental narrative in Secangkir Kopi Pahit together with location shooting in some of the tougher areas of Jakarta, presents a way of life in a Third World city that is perhaps not easily imagined by the citizens of developed countries. Secangkir Kopi Pahit is one of Teguh's most innovative films and it establishes him as one of the finest and most original film auteurs in Indonesia, able to make films that truly depict important aspects of the national experience that are rarely addressed in Indonesian cinema.

Throughout his filmmaking career, Teguh Karya draws upon a range of different dramatic and filmic possibilities, stimulated to some extent by his knowledge of drama as much as of film. If one talks of the history of realism in film, a major point of reference is Italian neo-realism. The main stylistic elements in Italian neo-realism were the use of black and white photography, which had about it a newsreel quality; a large amount of location shooting; use, to varying degrees of non-actors, and improvisation of situations to varying degrees. Also central to Italian neo-realist films (though not all) was the evocation of impoverished, traumatized and dislocated immediate post-war Italy. ${ }^{2}$ Of all Teguh's films, Secangkir Kopi Pahit achieves a powerful reality effect. This reality effect is achieved partly by very extensive use of filming location: in streets and busy intersections of Jakarta; in slum areas along the Tanah Abang railway line with its marginalized population and its numerous shanty dwellings; in a run-down losmen in Cirebon; in slum dwellings in shanty towns located near industrial developments. Nevertheless, the film is shot in color. How does Teguh manage to compensate for the effects of visual pleasure normally produced by the use of color? The powerful reality effect of Secangkir Kopi Pahit is enhanced by having its central character be a reporter working for a newspaper, who is also a photographer obsessed with the city in which he lives. Togar himself is not simply a character in the film, but contributes to the realistic presence of the city by his photographs of its poorer inhabitants which are there in the credits sequence, and elsewhere, and which we see him taking in the course of the film. We are encouraged to see people in the film not only as part of a narrative, but with a photographer and reporter's eye. Additionally, the complex and rapidly moving flashback structure emulates the sense of pressure and crowding that is the experience of the city. For Secangkir Kopi Pahit, Teguh has developed a new and unique repertoire of stylistic effects (complex flashback structure in addition to location shooting; central character a photographer and reporter obsessed with the city and with exposing situations). This produces a reality effect in filming the growing Third World megacity of Jakarta in the early 1980s.

\footnotetext{
${ }^{2}$ There are several key books on Italian neo-realism: e.g. Armes (1971), Brunette (1987), NowellSmith (2003), and Bazin (2004).
} 


\section{REFERENCES}

Abeyasekere, Susan. (1987). Jakarta: A History. Oxford: Oxford University Press Armes, Roy. (1971). Patterns of Realism. South Brunswick, NJ: A.S. Barnes

Bazin. Andre. (2004). What is Cinema? H.Grant (trans). Los Angeles: University of California Press

Bordwell, David. (1986). Narration in the Fiction Film. London; Routledge

Bordwell, David. (2005). Figures Traced in Light: On Cinematic Staging. Los Angeles: University of California Press

Bordwell, David \& Thompson, Kristin. (2010). Film Art: An Introduction. New York: McGraw-Hill

Bowen, J.R. (1986). On the Political Construction of Tradition: Gotong royong in Indonesia. Journal of Asian Studies, XLV (3), 545 - 561

Brunette, Peter. (1987). Roberto Rosellini. New York: Oxford University Press

Gabriel, Teshome. (1982). Third Cinema in Third World. Ann Arbor, Mich: UMI Research Press

Gabriel, Teshome. (nd). Third Cinema Updated: Explorations of Nomadic Aesthetics \& Narrative Communities. Retrieved from http://teshomegabriel.net/

Hadimaja. Ramadhan.K. (2012). Ali Sadikin: Membenahi Jakarta Menjadi Kota Manusiawi. Jakarta: Ufuk Press

Hadjor, Kofi Buenor. (1993). Dictionary of Third World Terms. London: Penguin Books

Hallam, Julia \& Marshment, Margaret. (2002). Realism and Popular Cinema. London: Manchaster University Press

Hanan, David. (2017). Cultural Specificity in Indonesian Film: Diversity in Unity. Switzerland: Palgrave Macmillan

Heider, Karl. (1991). Indonesian Cinema: National Culture on Screen. Honolulu: University of Hawaii Press

Jellinek, Lea. (1978). The Life of Jakarta Street Trader-Two Years Laters. Melbourne: Centre of Southeast Asia

Mamas, S.M \& Komalasari, R. (2008). Jakarta—Dynamics of Change and Livability. In G.W. Jones \& M. Douglass (Eds), Mega-Urban Regions on Pacific. Singapore: National University Singapore Press

Meng, X., Manning, C., Shi, L \& Effendi, T.N. (eds) (2010). The Great Migration: Rural-Urban Migration in China and Indonesia. Massachusets: Edward Elgar

Nowell-Smith.Geoffrey. (2003). Luchino Visconti. London: BFI

Riantiarno. Nobertus (ed, 1993). Teguh Karya \& Teater Populer 1968 - 1993. Jakarta: Pustaka Sinar Harapan

Marselli. (1985, July 21, p.7). Film Secangkir Kopi Pahit Yang Terasa Cukup Menyegarkan. KOMPAS 